\title{
PRÁTICAS DE CURA MÍSTICO-RELIGIOSAS, PSICOTERAPIA E SUBJETIVIDADE CONTEMPORÂNEA
}

\begin{abstract}
Abílio da Costa-Rosa'
Resumo: nalisamos os resultados de uma pesquisa sobre as práticas de cura místico-religiosas (Evangélicas e Católica Renovadas e Umbanda) e sua comparação com o tratamento dos Ambulatórios de Saúde Mental públicos, para indivíduos com queixas de sofrimento psíquico. A análise estatística revelou que as práticas de cura místico-religiosas são eficazes na solução dos problemas que as procuraram, superando, a curto prazo, a eficácia obtida pelas práticas ambulatoriais. Um dos principais meios da eficácia das práticas de cura místico-religiosas consiste na adição de sentido de vários matizes, com destaque para o sentido radical de teor imaginário, que implica em adesões institucionais do tipo fanático ou ritualístico, em boa parte dos casos. As práticas de cura místico-religiosas parecem funcionar como ortopedias das "doenças" do individualismo contemporâneo, repondo com meios sintônicos aos sintomas alguma funcionalidade da categoria indivíduo. Como desdobramento da análise chegamos à hipótese sobre a existência de uma "Cultura do Misticismo" em estado avançado de formação no contexto brasileiro, como conseqüência das características culturais e dos efeitos da perturbação das relações do sujeito com o campo do simbólico, nas sociedades de consumo globalizado: de acentuada exclusão social e afetadas por uma importante crise de sentido conseqüente ao abalo dos ideais mais basilares do liberalismo.
\end{abstract}

Palavras-chave: Cura místico-religiosa. Subjetividade. Psicoterapia. Saúde mental coletiva. Misticismo.

1 Este artigo compreende a re-elaboração da reflexão sobre de uma parte dos dados de uma ampla pesquisa realizada em São Paulo sobre práticas de cura místico-religiosas, apresentada em 1995 ao Instituto de Psicologia da USP como tese de doutoramento, com o título: “Práticas de cura nas religiões e tratamento psíquico na saúde Coletiva", sob orientação do Prof. Dr Ryad Simon. Suas idéias têm circulado apenas através da referida tese durante a última década; tendo sido veiculado, nesse meio tempo, apenas um artigo referente a uma pequena parte de suas conclusões (Costa-Rosa, 1999). Eu vinha tendo em conta que seus dados requeriam atualização para justificar divulgação mais ampla. Entretanto duas novas pesquisas orientadas por mim recentemente (em 2003 e 2004) sobre o mesmo tema mostraram que sua atualidade continua preservada. Dada a relevância desses dados e suas conclusões para a análise das práticas psicoterapêuticas na Saúde Coletiva e para a análise da subjetividade contemporânea, resolvi empreender sua divulgação mais ampla. 


\section{I - Práticas de cura místico-religiosas e contexto sócio-cultural}

\section{Universal e atual}

A relação entre religiosidade e curas remonta a tempos imemoriais da cultura ocidental. Os dados etnológicos indicam que ela, alem de ser praticamente uma constante universal das culturas, possui ênfase acentuada na atualidade (Haley, 1993; Lévi-Strauss, 1975; Magnani,1989; Montero, 1985; Platão, 1957; Terrin, 1996).

Neste trabalho procura-se discutir o tema com base em dados de uma pesquisa de campo que investigou algumas das principais práticas de cura oferecidas pelas religiões no contexto urbano de São Paulo, em comparação com os tratamentos realizados no Ambulatório de Saúde Mental da Rede Pública, para indivíduos com queixas de sofrimento psíquico.

Partiu-se da observação de que é cada vez maior o número de pessoas que vem recorrendo às instituições místico-religiosas ${ }^{2}$ em busca de soluções para todo tipo de males e problemas. Por outro lado, é igualmente visível a proliferação de grupos místico-religiosos, dos mais variados matizes, que parecem fundar sua pertinência social na oferta explícita de ajuda aos diferentes problemas do cotidiano individual. Essa proliferação de instituições e o crescimento do número de seus adeptos têm ocupado amplo espaço na mídia e nas preocupações dos intelectuais do setor, deixando inequívocas a atualidade do tema e sua importância (Antoniazzi, 1994; Magnani, 1989; Moreira \& Zicman, 1994).

O critério da predominância numérica orientou a decisão metodológica por dois grandes ramos desse vasto conjunto: a Umbanda, representando os cultos afro-brasileiros, com claras características xamânicas; e as Igrejas Pentecostais e Católica Renovadas, representantes dos cultos de origem judáico-cristã (especificamente, Igreja Universal do Reino de Deus, Pentecostal Deus é Amor e Carismáticos Católicos). Pelo interesse em analisar possíveis relações entre as práticas de cura místicoreligiosas e as psicoterapias, destacamos do conjunto dos pedidos de ajuda, pessoas que recorreram por queixas onde o fundamento orgânico era inexistente ou não diagnosticável, isto é, cujo sofrimento e os pedidos de ajuda eram claramente de natureza psíquica, e cujas características e condições eram comparáveis às do grupo de pessoas que recorreu ao Ambulatório de Saúde Mental Público pelos mesmos motivos.

2 Por um lado devido ao sincretismo da Umbanda: formação religiosa genuinamente brasileira de origem africana, indígena e católica (kardecista). Por outro lado pela função utilitarista, estereotipada e mistificadora da maioria das práticas das Renovadas. Mas, sobretudo, dado o inequívoco caráter vivencial e emocional, desses dois conjuntos de práticas, utilizadas a serviço da resolução de problemas cotidianos não confessionais, optei por me referir a elas como místico-religiosas. 


\section{Alguns estudos anteriores}

Freud (1932), em "O Problema da Concepção Unitária do Universo", analisa o que considera uma característica da vida psíquica humana: a exigência de resolução unitária de todos os problemas de nosso ser; essa tendência à totalização, de caráter afetivo, compreenderia uma solução psíquica frágil por ser resultante da dificuldade em lidar com o desamparo, a incompletude e a indeterminação das situações da vida concreta. Em "Psicologia das Massas e Análise do Eu" (Freud, 1921), ao estudar os grupos do tipo massa, caracteriza-os como uma formação particular em que o líder assume na subjetividade dos indivíduos a função muito mais de um objeto ideal de consistência narcísica e imaginária, do que de um suporte capaz de permitir ao indivíduo orientar-se na direção dos Ideais da cultura. A constituição das massas estaria relacionada a conjunturas em que, para os indivíduos, não estaria sendo possível marcar a distância entre o eu atual e o eu ideal; nesses casos, o líder como eu ideal seria requisitado para fazer as vezes do objeto de identificação, produzindo identificações imaginárias maciças do eu com o outro. Finalmente, em "O Futuro de uma llusão" (Freud, 1927), assinala que os homens, dependendo de sua disposição subjetiva, podem responder diferentemente aos enigmas ante os quais se choca seu desejo de saber, assim como pode variar sua tolerância ao desamparo que é condição básica de todos. Alguns exigem respostas de teor absoluto e totalitário, outros toleram mais a dúvida e a indeterminação. Freud parece acenar aqui com uma tentativa de diferenciar dois modos da consistência subjetiva, definidos segundo a consistência mais imaginária ou mais simbólica da relação o mundo.

$\mathrm{Na}$ Antropologia o tema tem sido tratado inúmeras vezes. Lewis (1971), critica uma linha de estudos que pretenderia reduzir fenômenos como o do êxtase religioso a supostas perturbações mentais dos indivíduos em que ele se manifesta. Não tem dúvida de que tais práticas desempenham uma função importante na resolução de conflitos do dia-adia, inclusive porque elas ocorrem associadas à participação em formações sócioculturais de alta relevância para a comunidade (festas e ritos religiosos coletivos).

Laplatine (1977) analisa o messianismo e a possessão, que considera dispositivos criados pelos oprimidos; observa que o primeiro fomenta o desejo mediante a espera, enquanto a segunda traduz a realização instantânea de um desejo de caráter absoluto. Afirma que estamos diante de duas formas de treatralização paroxística da existência, em que estão em jogo demandas de um gozo radical.

Lewis e Laplatine dão destaque, sobretudo, às funções de regulação subjetiva e sóciocultural dessas práticas para grupos sociais considerados não complexos (sociedades xamânicas). Não chegam, portanto, a considerar o caráter "endêmico" do fenômeno místico-religioso e suas 
manifestações propriamente urbanas, fato em parte explicável pelos objetivos de suas análises. Esse é um aspecto absolutamente sublinhado nas práticas de cura que iremos analisar: elas estão totalmente disseminadas nos interstícios da vida cotidiana, o que lhes tira o caráter de rituais de exceção que lhes era atribuído em sua função etnológica. Também parece inequívoco que agora elas visam diretamente o indivíduo e não mais o grupo social.

No contexto brasileiro também encontramos vários trabalhos destacando a questão da relação entre religiosidade e curas, tanto na Umbanda, quanto nas pentecostais (Brandão, 1994; Mariz, 1994; Montero, 1985; Paiva, 1990; Trindade, 1979).

Cabe especificar particularmente algumas afirmações de Montero (1985) sobre a Umbanda: ela

\begin{abstract}
resolve casos que a Medicina não consegue resolver... instaurando um espaço terapêutico que vai muito além da simples restauração do organismo doente...é capaz de articular várias dimensões da experiência mórbida (o orgânico, o psicológico, o social)... A reordenação da experiência subjetiva caótica, pelo mito, transforma qualitativamente a relação do eu com o mundo, abrindo caminhos através dos quais um certo arranjo das relações pessoais, do enfrentamento das questões e, conseqüentemente, das situações-problema se torna possível. (p. 25)
\end{abstract}

Os autores até aqui considerados, analisando o fenômeno geralmente sob uma ótica antropológica ou sociológica, não tiverem por meta principal a análise das repercussões específicas de tais práticas no psiquismo dos participantes; isso reafirma a pertinência de nosso enfoque, que procurou considera-las sob o prisma de suas relações com a subjetividade e o sofrimento psíquico.

Ainda no tópico dos estudos anteriores sobre o tema, há dois conjuntos de pesquisas cuja referência é imprescindível, dada a importância de suas questões e conclusões para o aprofundamento de nossa pesquisa: "Cultura do narcisismo" e "curas xamânicas".

$\mathrm{Na}$ análise dos fenômenos relacionados ao narcisismo destacamos principalmente dois autores (Lasch, 1983; Lindholm, 1993).

Lasch (1983) propôs os termos "Cultura do Narcisismo" procurando designar certas condições gerais das sociedades modernas: contínua desintegração das comunidades locais, isolamento individual, fragmentação de papéis, relações de trabalho insatisfatórias, rápida substituição de valores. Nesse contexto os indivíduos seriam compelidos a uma espécie de plasticidade camaleônica do eu, correlativa de vínculos emocionais cada vez mais superficiais, em que buscariam compensações de natureza narcísica através de vivências de matiz imaginário, cujo estatuto corresponderia ao das primeiras fases do desenvolvimento psíquico (regredidas). 
A Cultura do Narcisismo seria resultante do afloramento, em um grupo cada vez maior de indivíduos, de traços narcisistas presentes, a princípio, em todos, decorrente das condições sociais acima mencionadas. Daí resultariam "egos" enfraquecidos vulneráveis, entre outras possibilidades, às experiências de êxtase e aos vínculos carismáticos, como formas de compensação para suas defasagens psíquicas; isso acarretaria performances como insatisfação constante nos vínculos amorosos, que implicam em ligações efêmeras e superficiais, e no culto patológico do consumismo, como próteses de afirmação de valor pessoal.

Lindholm (1993) caminha na seqüência do trabalho de Lasch para propor uma relação entre o narcisismo e um conjunto de ocorrências contemporâneas que podem ser designadas pelos termos carisma e consumismo. Sua tese é que os contextos sócioculturais instáveis concorrem para a formação de personalidades ávidas de relações carismáticas, decorrentes do empobrecimento da subjetividade, com profundas implicações para as relações interpessoais. Nessas condições, certos indivíduos tenderiam a tomar o outro como um apêndice constitutivo da própria unidade do eu, estabelecendo vínculos carismáticos de extrema dependência. Esses vínculos podem ser experimentados como sensações de completude absoluta; o que faz pensar que para tais indivíduos o outro funciona como um representante direto dos objetos do momento narcísico ${ }^{3}$ do desenvolvimento psíquico em que predomina uma demanda subjetiva de completude imaginária. Essa demanda de completude pode expressar-se em adesões carismáticas a instituições de caráter místico-religioso como as Pentecostais Renovadas (a isso associa um dos fatores da sua proliferação), e também em diferentes graus de compulsão consumista, que pode chegar ao vício em drogas. Lindholm relaciona o surgimento desse estado a insatisfações com a figura paterna, quanto a seus efeitos no processo de constituição subjetiva (p. 104). Sua análise está de acordo com a de Freud (1921), que considera que esse é o mecanismo básico da relação dos componentes da massa com o líder carismático: o outro/líder tende a fixar-se no lugar do Ideal do eu do indivíduo, em vez de representar um parâmetro transitório para a construção de uma identidade singular.

Tanto Lindholm quanto Lasch insistem em que as personalidades narcísicas e carismáticas têm seu aparecimento associado a contextos em que predomina o Modo de Produção Capitalista em suas formas de-

3 Tempo da constituição subjetiva que, segundo Freud (1914), se caracteriza por relações em que o objeto é concebido com exigências radicais de completude, instantaneidade e caráter absoluto. Este tempo tem sua função específica necessária dentro dessa constituição como processo mais amplo, que inclui três tempos. 0 caráter problemático do narcisismo ocorre quando este tempo fica pendente em sua resolução e retorna como marcas de funcionamento (regredido) em subjetividades nas quais o processo pode ser dado como realizado. 
senvolvidas (neoliberal globalizado), nas quais os padrões éticos estão conturbados e as formas de autoridade perderam a legitimidade: contínua desintegração das comunidades locais, profundo isolamento e alienação dos indivíduos perdidos na fragmentação de papeis, relações de trabalho insatisfatórias, insegurança quanto ao futuro mesmo mais imediato, proliferação de imagens nos meios de comunicação operando a substituição de valores enraizados por outros de consistência mais efêmera; nessas condições a própria sociedade tenderia a ser percebida como destituída de forma institucional autêntica, exacerbando-se o individualismo.

A partir da análise dessas considerações, é possível propor que a hipótese central implícita sublinha a incidência, na subjetividade, das condições socioeconômicas e culturais perturbadas, cujo efeito é a alteração do processo de constituição da subjetiva a ponto de produzir um enfraquecimento das relações dos indivíduos com o campo do simbólico; ou seja, para eles há um velamento dos Ideais sócioculturais como parâmetros da espera plausível. Esse enfraquecimento poderia traduzirse, entre outros efeitos subjetivos, em vulnerabilidade a experiências de êxtase, de consumismo compulsivo e de vínculos carismáticos, todas indicativas da presença, nessas subjetividades, de demandas radicais de completude imaginária ${ }^{4}$, portanto de teor regredido.

As hipóteses desses autores nos forneceram importantes elementos teóricos para compreendermos um aspecto que assumiu importância fundamental para a caracterização dos sujeitos que foram alvo de nossa pesquisa: está presente neles um importante traço místico-religioso. Isso nos permitiu propor a hipótese da existência, para eles, de um contexto de Cultura do Misticismo, que pretendemos fundamentar neste trabalho. Pretendemos demonstrar que à mesma ordem de fenômenos tratados como fenômenos narcísicos, carismáticos ou em termos de compulsões, acrescenta-se, nos contextos urbanos brasileiros, um traço fundamental que se expressa no exercício cotidiano de diferentes misticismos, como atitudes arraigadas. A Cultura do Misticismo faz parte de um amplo leque de possibilidades de saída. Diante dos diferentes impasses sócioculturais e subjetivos, os indivíduos responderão de diferentes formas, no fundo congruentes (com exceção da saída pela militância também possível e fundamental): alguns sairão pelo

4 A completude imaginária pode ser definida sucintamente como a exigência instantânea e estática de fazer Um com o outro, ou com outros objetos de regulação psíquica. Também pode expressar-se como demanda radical de sentido total vindo de fora. A psicanálise define o Um da unificação por oposição ao Um da unidade; este supõe a presença de uma instância terceira para se produzir a possibilidade subjetiva de contar e de se contar numa cadeia que é simbólica (Lacan, 1979). A persistência na exigência do Um da unificação tem caráter regredido e seria expressa em vínculos como a identificação carismática, no consumismo compulsivo e na própria efemeridade dos vínculos amorosos. 
consumismo das mercadorias comuns, outros pela violência ativa ou passiva, outros pelas adições compulsivas (diferentes toxicomanias), outros pelas adesões místicas (configurando uma "Cultura do Misticismo"), outros pela inanidade social e subjetiva (mendicância) e outros, finalmente, adoecendo em tradução simples.

No tópico da relação entre curas místico-religiosas e eficácia simbólica é suficiente nos referirmos ao trabalho fundamental de Lévi-Strauss (1975), em que discute os fundamentos e resultados de uma série de práticas xamânicas de cura. Assinala tratar-se sempre de processos que vêm ao encontro de vivências individuais que são, na origem, intelectualmente informes e afetivamente intoleráveis; diremos que expressam vivências subjetivas de crise que ao serem incorporadas a um esquema de explicação presente na cultura do grupo encontram um meio de objetivação.

Esse princípio de "objetivação de estados subjetivos" (p. 198) pode ser levado a extremos nos procedimentos da "concretização" nos quais se trata de "produzir" sob a forma de um objeto material, a doença a ser tratada. Um exemplo dessa técnica o caso do "tufo de pelos ensangüentado"." Trata-se do uso de um pequeno tufo de penugem que o prático dissimula num canto da boca para retirá-lo todo ensangüentado no momento oportuno, após se haver mordido a língua ou ter feito brotar o sangue das suas gengivas, e apresentá-lo solenemente ao doente e à assistência, como o corpo patológico expulso em conseqüência das suas manipulações" (p. 203). Lévi-Strauss mostra que o portador dessa técnica é capaz de triunfar em uma série de casos em que seus colegas, com o uso das técnicas mais sofisticadas tinham fracassado.

Daí podemos tirar uma conclusão importante para nossa pesquisa: as práticas xamânicas têm sua seletividade e o mesmo parece ocorrer com as práticas de cura místico-religiosas. Como explicar o triunfo da técnica de "concretização" nos casos em que as outras já haviam fracassado?

Juntando a essas considerações teóricas um primeiro percurso pelos dados de nossa pesquisa, formulamos a hipótese de que esses casos, julgados desesperadores por resistirem às soluções mais comuns, são justamente aqueles em que apenas as soluções plasmadas de sentido imaginário ${ }^{5}$ eram passíveis de prevalecer. $O$ sucesso da "cura" parecia depender, sobretudo do encontro de subjetividades portadoras de demandas radicais de significação de teor imaginário com "técnicas" fundadas na oferta radical de sentido de mesmo teor, na mesma proporção. Parece que respostas de teor simbólico não tinham função em subjetividades cuja demanda era de adição de sentido de natureza imaginária. Esta hipótese bem como as idéias anteriores nos servirão de fundamento para

5 Podemos definir o sentido imaginário como aquele que vem inteiramente do Outro como significado dado para ser enxertado na subjetividade, e que tem caráter radical quanto à sua potência:é posto como total, instantâneo e, às vezes, transcendente. 
a compreensão das práticas de concretização e das "curas impossíveis" realizadas nas Igrejas Pentecostais Renovadas: processos como adesão pela fé, reação catártica, tradução de angústias individuais em mitos coletivos de alta densidade simbólica e "concretização" são comuns nas práticas de cura das Igrejas Renovadas e da Umbanda.

\section{Objetivos, hipóteses e metodologia da pesquisa}

Partiu-se dos seguintes objetivos: aferir se há ou não eficácia terapêutica nos procedimentos autodesignados como práticas de cura, oferecidas publicamente pelas instituições místico-religiosas (Renovadas: Evangélicas e Católica, e Umbanda); inclui-se sua comparação com as práticas, supostamente com a mesma finalidade, oferecidas pelos Ambulatórios de Saúde Mental da Rede Pública; elaborando um desenho metodológico que permitisse tratar estatisticamente os resultados desta parte dos dados. Além de aferir a eventual eficácia das práticas de cura místico-religiosas e as possíveis características diferenciais entre os três grupos de indivíduos (Renovadas, Umbanda, Ambulatório), incluímos o objetivo de levantar os possíveis pressupostos em que se fundamenta tal eficácia e quais as características e o valor de seus efeitos. Ou seja, investigamos qual é o fundamento da sua eficácia terapêutica e qual o estatuto ético dessa eficácia.

Utilizaremos as hipóteses em dois sentidos. Primeiro dando-lhe a função que têm no método das ciências naturais: proposições a serem confrontadas com os dados quantificáveis e analisadas segundo os parâmetros do "método estatístico" de verificação de hipóteses. Segundo, com a função principal de orientar o processo de pensamento no percurso de análise ampla do fenômeno - como hipóteses de trabalho.

O conceito de hipótese de trabalho surgiu com o fim de distinguir o valor cognitivo de diversos tipos de hipóteses. Chama-se habitualmente hipótese de trabalho a uma das primeiras explicações dos fenômenos, que se prestam por certo período de tempo como instrumento de sucessiva investigação do objeto. (Koponin, 1978, p. 253)

Cada um desses dois modos de utilização das hipóteses toma como referência dois modos sob os quais foram apreendidos os dados neste estudo. Num caso trata-se de dados das entrevistas com os adeptos, em que a quantificação foi possível e se julgou proveitosa. No outro se incluem dados decorrentes de aspectos gerais dessas entrevistas que não foi possível, ou que se considerou menos adequado, quantificar. Foram incluídos, ainda, dados a serem tratados qualitativamente, provenientes da observação participante das sessões de cura (realizamos verdadeiras imersões fenomenológicas nos rituais coletivos), da Umbanda e das Igre- 
jas Renovadas; alem de dados de entrevistas livres com os pastores e"pais de santo".

Algumas das hipóteses firmadas, tentando apreender a questão na sua maior complexidade possível, são as seguintes:

Haverá ou não eficácia terapêutica das práticas de cura na Umbanda e das Igrejas Renovadas?

Haverá ou não diferenças de grau na eventual eficácia terapêutica entre os três grupos da amostra (incluindo o Ambulatório de Saúde Mental da Rede Publica)?

Em que pressupostos se fundamenta e com que meios se realiza a possível eficácia terapêutica das práticas místico-relgiosas?

Qual seria a circunstância mais comum da recorrência às religiões: nas crises agudas, ou em situações cronificadas nas quais o saber oficial fracassou?

Como serão definidas as fronteiras entre perturbação espiritual e patologias re-encaminhadas à ciência?

Qual o papel desempenhado pela consonância cognitiva decorrente do compartilhamento de crenças (cliente-prática de cura)?

Quais as relações possíveis entre curas obtidas declaradas e eventuais efeitos na subjetividade e na vida dos indivíduos?

Seria possível estabelecer alguma relação entre a "situação terapêutica" das práticas de cura místico-religiosas e a situação das psicoterapias fundadas na psicanálise?

Quanto aos sujeitos, foram consideradas apenas mulheres casadas, pertencentes a extratos sócio-econômicos baixos ( $C$ e D), devido aos objetivos da pesquisa, e à necessidade de maior homogeneização da amostra, pois, sendo os homens mais raros, não foi possível construir grupos paritários.Também foi necessário excluir da amostra dos Ambulatórios os indivíduos com diagnóstico de psicose, dada sua raridade nas práticas de cura místico-religiosas.

Os dados foram colhidos com base em dois tipos de levantamento, dependendo das informações que se queria obter. A eficácia terapêutica foi medida através das variações da eficácia e adaptativa dos sujeitos às exigências do cotidiano, e levou em conta uma entrevista clínica aplicada aos três grupos de sujeitos em dois momentos consecutivos: início da freqüência às práticas de cura, e transcorridos três meses de freqüência. Foram entrevistados 97 indivíduos eqüitativamente distribuídos entre os que procuraram ajuda no Ambulatório de Saúde Mental, nos Terreiros de Umbanda e nas Igrejas Renovadas. Esses grupos foram construídos com base em entrevistas preliminares realizadas com aproximadamente 350 indivíduos. A entrevista da qual foram extraídas as informações quantificadas, bem como a análise dessas informações apoiou-se fundamentalmente no trabalho de Simon, 1983, o que permitiu analisar os efeitos das práticas de cura em termos da sua repercussão na eficácia 
adaptativa ${ }^{6}$ dos indivíduos em quatro áreas. Esse referencial permitiunos também o tratamento estatístico dessa parte dos dados, o que autorizou afirmações mais criteriosas. (A análise estatística utilizou o SPSSPC/5.01-Statistical Package for Social Science e"testes de hipóteses para comparação de médias de três populações não-correlatas: Análise de Variância-Teste de Tukey"). Há também uma série de informações que achamos importante apresentar em suas porcentagens de ocorrência.

As outras hipóteses da pesquisa, que visavam compreender os fundamentos da eficácia de ação das práticas de cura e outros aspectos importantes do estudo, foram analisadas através da construção de categorias e hipóteses, com fundamento nos métodos de análise Hermenêuticadialética (Minayo, 2000) e na Psicanálise (Silva, 1993).

É importante esclarecer que não tivemos a pretensão de estudar nem as religiões nem o xamanismo como tais, mas justamente apenas alguns desdobramentos atuais instrumentados em suas práticas: os serviços específicos que prestam a uma clientela assídua, cada vez mais freqüente, constituída por indivíduos vindos, um a um, em busca de respostas diretas a seus impasses cotidianos.Também procuramos não confundir a realidade das interpretações dadas a certos sinais percebidos pelos indivíduos com a pretensa realidade desses sinais; com isso não foi preciso lançar mão de hipóteses que transcendam o campo especificamente humano.

II - As práticas místico-religiosas: características, eficácia e ética

1 Formas de aparecimento dos pedidos de ajuda, dos modos da"transferência" e do "posicionamento subjetivo"

Os pedidos de ajuda nos grupos de indivíduos que recorreram às Renovadas e à Umbanda mostraram uma porcentagem de queixas psíquicas, e somáticas junto com psíquicas, que ultrapassou $70 \%$ do total, os demais se distribuíram entre problemas de parentes próximos, geralmente alcoolismo e drogadições; problemas econômicos (incluindo desemprego) e desarranjos familiares. As queixas do grupo que recorreu aos Ambulatórios também são muito semelhantes, em termos descritivos, às das práticas místico-religiosas e servem perfeitamente de modelo para sua expressão:"angústia",'abafamento,"'dores pelo corpo,"'nervo-

6 A eficácia adaptativa foi considerada a resultante do modo como apareciam equacionados para os indivíduos entrevistados quatro setores da sua vida e da sua subjetividade (Afetivo-Relacional - AR, Orgânico e psíquico - Or, Produtividade - Pr e Sócio-(ultural - SC), em termos da satisfação ou insatisfação do equacionamento conseguido e da presença ou ausência de conflitos, como resultado desse processo. 
sismo", "alcoolismo" e queixas de sofrimento psíquico mais extremo em quadros de histeria grave (Maleval, 1987), entre outras. Destaque deve ser dado ao fato de que, já nas primeiras informações, as práticas das Pentecostais Renovadas apresentaram um subgrupo de queixas que era definido como "problemas impossíveis", ausente nas demais instituições pesquisadas.

Procurou-se compreender o modo como os indivíduos designavam os "objetos" de sua busca. Denominamos a essa atitude "modo da disposição inicial para a transferência",sendo esta entendida, com Lacan (1979), antes de tudo, como transferência de saber ${ }^{7}$. Aqui também os dados se mostram altamente significativos. Sua análise permitiu designar quatro possibilidades básicas no conjunto das ocorrências: "buscar um objeto utilitário," "buscar um saber místico" (revelação divina), "buscar um saber racional" (saber de mestre) e "buscar saber" (implicado subjetivamente em saber também por si, abrindo a possibilidade do saber inconsciente). A aplicação destas categorias aos dados deverá tornar mais claros os sentidos de cada uma.

Entre os vinculados às Renovadas, $78 \%$ estavam em busca de um saber em forma de revelação mística, assumindo em relação a esse saber uma posição de absoluta exterioridade; ou seja, como era esperado, trata-se de um saber que está fora do sujeito, este permanece alienado quanto às razões de seu sofrimento e de sua cura. Essa atitude transferencial manteve-se, ainda mais acentuada, depois de três meses de freqüência (90\%). A atitude transferencial buscar um objeto utilitário foi observada no grupo de indivíduos que participa das sessões de cura realizadas durante os cultos comuns. Algumas destas pessoas possuíam demandas urgentes de ajuda; vinham aos cultos como quem fosse à missa confessar-se e comungar em momento de culpa intensa ("vim tomar oração", "vim em busca do que Jesus tem preparado para mim","estou à espera de um milagre","vim porque minha vizinha falou que é muito bom," "venho porque saio aliviada"). As outras duas possibilidades transferenciais não ocorreram para os freqüentadores das Renovadas, conforme o esperado.

Nos vinculados à Umbanda encontramos $80 \%$ em busca de um saber sob a forma de revelação mística; essa atitude transferencial apresentava-se pouco alterada após três meses de freqüência . A busca de um objeto utilitário foi observada em $16 \%$ dos freqüentadores constantes e esporádicos, que participavam das sessões rituais regulares e que se apresentavam como clientes no momento de atendimento à população aberto durante essas sessões, denominado "trabalhos de caridade" ("vim to-

7 Transferência de saber: quando o sujeito recorre a um tipo de ajuda, ele o faz a partir da suposição de que há saber capaz de resolver os seus problemas. Só que, devido a sua alienação, ele supõe, no mesmo ato, que esse saber é o outro quem o tem; no caso das práticas místico-religiosas esse outro pode adquirir características transcendentais. 
mar passe", como quem tomasse um comprimido;"vim buscar orientação com os orixás"', vim para o orixá benzer minha carteira de trabalho"). Como previsto, as outras duas possibilidades transferenciais também não ocorreram para os freqüentadores da Umbanda.

Nos indivíduos que estavam freqüentando os Ambulatórios, ocorreu a circunstância que era esperada numa situação em que a medicação é o primeiro e mais freqüente recurso utilizado como resposta às demandas de ajuda: $37 \%$ revelaram estar em busca de um remédio que tinha claramente a consistência de um objeto utilitário, do qual parecia esperarse que agisse a partir do exterior e à revelia dos sujeitos. Após três meses de iniciado o atendimento encontramos uma acentuação significativa dessa atitude transferencial: $74 \%$ estavam tratando-se apenas medicamentosamente, aparentemente depositando aí sua expectativa de cura, embora ente eles alguns ainda estivessem aguardando psicoterapia. Os demais indivíduos distribuíam-se entre buscar um saber racional (pedidos de orientação, conselhos: sujeitos encaminhados à psicologia pelo médico) e buscar saber. Nesta última possibilidade, a mais rara, encontram-se os indivíduos que demonstram alguma possibilidade subjetiva de deslocar suas queixas para um certo questionamento sobre o sentido delas, ao mesmo tempo em que parecem capazes de se incluir, tanto como parte da causas dos problemas, quanto da solução; pode-se dizer: querem saber e não apenas o saber do Outro que os atende. Vale a pena sublinhar que essa é uma posição exclusiva da clientela dos Ambulatórios. Sua raridade, mesmo após certo tempo de iniciado o tratamento, pode ser devida ao modo como estão organizadas essas instituições: predominantemente medicamentosas e com poucos dispositivos fundados na possibilidade de escuta analítica; também não se pode dizer que haja, nas instituições públicas fundadas no saber oficial, qualquer representação social da atenção ao sofrimento psíquico que inclua essas características, - a representação comum ainda é associada ao médico e à medicação (dados de observação).

Outro foco importante da análise da atitude subjetiva dos indivíduos foi procurado nas possíveis funções que a adesão ao "tratamento" poderia estar ocupando na vida e na subjetividade. Avaliamos que esse dado teria sua consideração mais relevante no momento da re-entrevista, e o designamos como posicionamento subjetivo ou implicação subjeti$v a$. Esta pode ser definida como o modo do sujeito se posicionar em relação aos conflitos e contradições que atravessa e pelos quais é atravessado. Ou seja, nesse aspecto da pesquisa procurou-se o significado que os indivíduos atribuíam à experiência que viveram ou estavam vivendo, tanto em termos do sofrimento, quanto do tratamento e da cura. Também aqui a diversidade dos dados nos permitiu designar quatro possibilidades básicas no conjunto das ocorrências:"engajamento pela fé", "fé com fanatização", "engajamento no ritual" e "singularização". Estas categorias 
tentam definir os modos como se expressou a adesão às práticas de cura, produzindo diferentes modos de estabilização psíquica, tanto nas situações que compareceram inicialmente em busca de ajuda, quanto nas próprias subjetividades.

Entre as Renovadas encontramos $46 \%$ vinculados pela fé, mas sem fanatização e $44 \%$ vinculados pela fé fanaticamente. Por outro lado, uma certa dose de ritualização parece estar presente nos engajados pela fé, pois há uma série de atividades e obrigações que têm que ser cumpridas para que a "mágica" dos efeitos conseguidos se mantenha, embora estas obrigações pareçam advir mais dos preceitos institucionais do que da disposição da subjetividade individual. Por exemplo, casos que se vêem arremessados de novo às situações sociais e subjetivas de crise iniciais, depois de um período de melhora, costumam ser interpelados e "interpretados" pelos pastores no sentido de reatarem sua freqüência regular aos "cultos" e regularizarem os pagamentos do dízimo, a pretexto de que a "normalidade" se restabeleça. A singularização não foi observada, como era esperado, dada a massificação dos ritos e mitos das Renovadas, situação que não varia nem no caso dos carismáticos católicos.

$\mathrm{Na}$ Umbanda $67 \%$ foram designados como engajados pela fé e outros $27 \%$ iniciaram o "desenvolvimento no santo", que inclui engajamento no ritual (ritualização da vida cotidiana e da subjetividade); essa ritualização aparece como saída para um conjunto de indivíduos que parecem confrontar-se, no momento da procura, com impasses estruturais da subjetividade (momentos de crise em neuroses crônicas graves dados de observação). No grupo dos engajados pela fé da Umbanda observa-se também alguma ritualização esporádica e circunscrita a "trabaIhos de cura" realizados em situações de crise, geralmente desencadeadas por impasses associados a fatores externos e contingentes. Observou-se a inexistência da estabilização pela fé fanática, dado que parece coerente com o modo como na Umbanda são postos em ação os mitos e os rituais, conservando a dimensão simbólica dos processos subjetivos e sócioculturais. Quanto à possibilidade de ocorrência do modo de estabilização psíquica por singularização nas práticas da Umbanda, podese dizer que a especificidade das saídas, propiciadas por ela nos casos de "desenvolvimento no santo", leva em conta a disposição particular de cada indivíduo para a eleição de uma ou outra das várias linhagens de deuses e espíritos do panteão afro-indígena (orixás:entidades das águas, das matas, etc.), que vão compor o modo particular da sua ritualização. Há, portanto, alguma possibilidade de escolha singular, embora dentro de possibilidades pré-estabelecidas nos mitos e rituais. Essa possibilidade de escolha, não parece, entretanto, sem importância subjetiva. 
O Ambulatório de Saúde Mental apresenta uma circunstância peculiar quanto à implicação subjetiva: $57 \%$ dos indivíduos tiveram de ser incluídos em uma quinta categoria, que pode ser descrita com o termo "desconectado"; ou seja, não parecia detectar-se neles qualquer atitude semelhante a engajamento ou vinculação, o que, entretanto, não pareceu impedir que um subgrupo continuasse esperando passivamente a solução, do medicamento; e que outros continuassem freqüentando suas psicoterapias, mesmo sem referirem mudanças significativas. As outras possibilidades de implicação subjetiva não foram observadas, exceto em caráter de exceção, o que também podia ser previsto, dadas a característica destas instituições e sua representação no imaginário social (predominantemente médicas e fornecedoras de suprimentos medicamentosos - dados de observação).

Entretanto, foi na população atendida no Ambulatório que se observou um dado que não ocorreu em outro setor da pesquisa: trata-se da implicação subjetiva que foi chamada singularização propriamente dita, caracterizada pelo engajamento na via desejante. Aqui a ajuda recebida não parece ter essa marca característica da fé, geralmente originada nas subjetividades em que parece estar dificultado o confronto com a incompletude, com a dúvida e com a indeterminação, e que são portadoras de demandas de sentido radical e pronto, vindo do Outro. A singularização, bem rara, parece estar associada à presença de psicoterapias fundadas na Psicanálise e também àquela disposição do posicionamento transferencial inicial designada como "buscar saber", anteriormente referida.

Como síntese da análise dos modos da implicação subjetiva, podemos dizer que entre os diferentes modos de solução de problemas usufruídos pelos indivíduos, no conjunto, quatro formas se destacaram por suas características, sua complexidade e pelos efeitos diferenciais produzidos: a fanatização, típica de um setor importante dos Pentecostais Renovados; o desenvolvimento no santo, que envolve ritualização da existência, típica da Umbanda; a desconexão, nos problemas psíquicos que receberam resposta apenas medicamentosa; e a singularização que é, conforme esperado, um efeito possível das práticas da psicoterapia psicanalítica, e que parece capaz de propiciar alguma abertura para o saber inconsciente e para a atitude desejante.

2 Modos do "tratamento" recebido nos três grupos: características da oferta de possibilidades transferenciais

Procurou-se especificar teoricamente os tipos de acolhida oferecidos pelas diferentes práticas de cura estudadas. Como nosso pano de fundo era a teoria psicanalítica da transferência, optamos por designar este aspecto de "características da oferta de possibilidades transferenciais", 
isto é, tivemos como objetivo investigar como o tipo de acolhimento oferecido pôde induzir um tipo de transferência de saber a ser realizado pelos "clientes".

Nossa hipótese é que um dos fatores principais que decidiu o desdobramento dos pedidos de ajuda, com suas diferentes formas de disposição transferencial inicial, terá sido o próprio modo como eles foram recebidos e escutados, ou seja, seu resultado dependeu do modo das ofertas de possibilidades transferenciais.

Pode-se dizer que predominou uma oferta em que está presente a esperança imaginária de que existem o amor e o saber, e que é um Outro quem os detém, tanto para a Umbanda quanto para as Renovadas, e até para uma parcela importante da população que procurou o saber oficial (Ambulatórios). A diferença está apenas nas formas de concepção desse Outro. Essas posturas parecem ter como efeito o encerramento das queixas em uma espécie de saber "a priori" que tende a deixar pouco ou nenhum espaço para qualquer tipo de interlocução verdadeira. Os contornos dessa oferta parecem induzir os indivíduos a depositarem num Outro (orixá, deus ou médico), de maior ou menor onipotência, o saber consciente e inconsciente que possuem sobre seus problemas; alguma exceção a essa regra cabe apenas a um conjunto bastante restrito das práticas psicoterapêuticas.

Nos Ambulatórios destaca-se a oferta da medicação (69\%) e do discurso médico Psiquiátrico ${ }^{8}$, como modos preponderantes de resposta para as demandas de interlocução sobre o sofrimento psíquico. Merece relevância o fato de que se, por um lado, as ofertas de psicoterapia foram escassas, por outro, houve quem a tenha recusado; e do grupo ao qual ela foi oferecida e aceitou, metade ainda estivesse aguardando após três meses.

Nas Igrejas Pentecostais Renovadas merece destaque um dos setores de suas práticas explícitas: a oferta de "curas impossíveis", fundadas numa manipulação das experiências com o sagrado, que incluem a concretização de males e amuletos, e nas quais cabe um destaque importante para adições de sentido de caráter total e instantâneo, e vivências de cunho emocional no contato com o transcendente. Dois exemplos são suficientes para ilustrar a situação: num caso o pastor conta a lenda bíblica em que Davi mata Golias, a seguir coloca no palco um gigante de isopor e vende pedras para que com elas os fiéis "derrubem seus gigantes interiores" (relatada na imprensa); no outro, uma moldura de porta é colocada no centro da igreja por onde se passa para ser aben-

Discurso que considera apenas a existência do saber da consciência a ser extraído do sujeito, mais ou menos colocado no lugar de objeto, pelo psiquiatra, seu operador principal. Quando sua operatividade é esperada para alem da química, entra em ação um saber do tipo enciclopédico, portanto, pré-estabelecido para o sujeito. 
çoado, transpondo instantaneamente a passagem de uma situação difícil para outra nova (dados de observação).

Os pastores conclamam e induzem de modo ostensivo os indivíduos a uma atitude onipotente, sustentada na própria potência absoluta de Jesus. É, comumente, a este setor da clientela que se associa o resultado que inclui a fanatização ${ }^{9}$. No cerne dessas ocorrências das Renovadas está a prevalência do Outro (Deus/Jesus), que é detentor de um saber absoluto sempre resguardado, uma vez que nunca é de todo revelável para o sujeito. Há momentos de propiciação de estados de êxtase e também de possessão induzidos pelo clima criado pelas palavras dos pastores e pelos cânticos de que todos participam. Os maus espíritos são evocados para serem queimados em nome de Jesus (agora metaforicamente).

$\mathrm{Na}$ Umbanda destaca-se um conjunto de casos para os quais parece fazer-se uma oferta que tem alguma compatibilidade com a demanda de singularização - são os casos indicados para "desenvolvimento no santo" (neuroses graves, às voltas com intensidades muito altas de angústia). Aqui há uma gama bastante ampla de procedimentos, configurando um processo, que vão desde a continência imediata do sofrimento do sujeito até a interpretação simbólica, por parte da mãe ou pai-desanto; passando por prescrições de "purificação", abstinências, jejuns, interdições, batismo e "renascimento", incluindo a participação em rituais no Terreiro, na encruzilhada ou na mata.

Conforme o próprio nome indica, a oferta de possibilidade de "desenvolvimento no santo" acaba permitindo uma certa regularização da vida psíquica, em que uma angústia que era extremamente intensa e desordenada (transbordante por toda a superfície do corpo), transformase em angústia suportável e vivenciada apenas nos momentos do ritual.

Merece destaque também a oferta de sessões de "caridade" em que os pais e filhos de santo incorporando as entidades atendem, de modo pontual, uma gama variada de problemas dos freqüentadores habituais ou esporádicos, da população vizinha. Estes freqüentadores pareciam comparecer como "quem ia à missa", ou mesmo ao médico, com a vantagem de que podiam expor diretamente ao "santo" seus diferentes impasses: administravam-se conselhos, banhos de ervas, benzeduras e passes.

9 Fanatização: contextos sócioculturais em crise pelo fechamento de perspectivas concretas e de Ideais de desenvolvimento e mobilidade social,, conjugados a personalidades narcísicas, que deixam tais indivíduos prisioneiros de demandas subjetivas radicais de sentido de teor imaginário. 0 preenchimento urgente e sem falhas dessa demanda é para eles fator de estabilização psíquica. Porém, por sua fragilidade simbólica, essa estabilização não deixa de ser claudicante. Daí esse lado ativo do fanático, que é uma tentativa de conjurar, por uma espécie de performance proselitista, a fragilidade de sua verdade. Sua tarefa é infinita, uma vez que não há um número suficiente de confirmações para a verdade absoluta de sua causa. 
Outra característica diferencial da Umbanda, quanto a sua oferta de possibilidades de interlocução, em comparação com as Renovadas, de caráter utilitarista e secular, é o fato dela operar sobre a base de mitos de grande densidade simbólica, que estão amplamente disseminados no imaginário e na cultura de parte importante da população brasileira.

\section{A eficácia das práticas de cura místico-religiosas}

Os resultados indicam que as práticas de cura das Igrejas Renovadas e dos Terreiros de Umbanda produziram ganhos estatisticamente significativos na adaptação dos indivíduos que a elas recorreram, quanto aos aspectos Orgânico (e psíquico), Afetivo-relacional, Sóciocultural e Produtividade. Interferiram também positivamente de modo decisivo, naqueles casos que estavam em crise psíquica. As práticas das Renovadas apresentaram maior eficácia terapêutica do que as da Umbanda, embora a diferença não seja estatisticamente significativa.

A eficácia terapêutica das práticas de cura místico-religiosas ganha maior relevo quando comparada ao efeito das práticas ambulatoriais, medido em circunstâncias e com meios semelhantes, para os mesmos problemas de natureza psíquica. Para um igual período de ação, os Ambulatórios de Saúde Mental da Rede Pública não mostraram efeitos de melhora, nem nas crises, nem na capacidade adaptativa dos indivíduos que os procuraram. Uma primeira explicação pode ser baseada no fato de que nos Ambulatórios pesquisados, naquele momento, as práticas de cura eram baseadas fundamentalmente na medicação como estratégia de tratamento dos problemas psíquicos, o que, como se sabe, nem sempre costuma produzir bons resultados, em curto prazo, nos casos de neurose. $A$ análise qualitativa mostrará outros fatores que possivelmente influenciaram esse resultado, bem como poderá ajudar a compreender a eficácia das práticas de cura místico-religiosas.

Para fundamentar a análise da eficácia terapêutica das práticas de cura nas religiões são de particular interesse as observações feitas anteriormente sobre o conceito de eficácia simbólica e sobre os elementos imaginários e simbólicos em que se fundamenta.

Embora, como vimos, as práticas de cura nas religiões, quando consideradas globalmente, possuam um conjunto de procedimentos que são apresentados aos clientes de modo mais ou menos estático; não há dúvida que tais procedimentos possuem aplicação e utilização seletiva. Assim, por exemplo, os procedimentos de concretização ou materialização são utilizados apenas em alguns casos, e têm funções e manifestações bem diferentes na Umbanda e nas Pentecostais. O mesmo ocorre com os procedimentos de efeito catártico, com a função atribuída às palavras utilizadas, e ao próprio tom em que são proferidas. 
Considerando o lado dos curandeiros, é preciso distinguir por trás do semblante espetacular do ritual suas características mais estruturais, e ao mesmo tempo, em nosso caso, as diferenças entre Pentecostais e Umbanda. Em nenhum caso dos que presenciamos pareceu tratar-se de representar apenas mimicamente os acontecimentos a partir dos passos rituais. Estes, para que haja efeitos de mudança no estado dos consulentes, têm que ser vivenciados, representados em sentido forte, em toda a sua originalidade e violência, tanto por parte dos curandeiros quanto dos consulentes.

Sob este aspecto as práticas de cura nas religiões podem ser consideradas também uma espécie de palcos do cotidiano onde se representam, vivenciam e equacionam vários impasses sócioculturais e subjetivos.

Há múltiplas nuances nas funções e significados assumidos pelos "corpos" nesta ação, porém uma dessas dimensões parece destacar-se. Nestes momentos agonísticos, que Laplatine chamou de teatralização paroxística da existência,

o corpo exprime a cada momento as modalidades da existência, e... não se trata apenas de representar com seu corpo um drama que se passaria 'na sua consciência'.... Como os fiéis que nos mistérios dionisíacos invocam os deuses, imitando cenas de sua vida..., o Deus está aí quando os fiéis não se distinguem mais do papel que representam, quando seu corpo e sua consciência deixam de opor-Ihe sua opacidade particular e se modelam pertinentemente ao mito... conseguem tornar-se o que fingiam ser: essa massa sem olhar e quase sem pensamentos, presa num ponto do espaço, que só está no mundo devido à vigilância anônima dos sentidos. Sem dúvida, é este último laço que torna possível o despertar. (Merleau-Ponty, 1971, p. 172 e 174)

A função assumida nos rituais pelo corpo, como âmbito e canal principal dos acontecimentos, destaca-se nas duas modalidades de práticas místico-religiosas estudadas: ressalta-se o aspecto catártico nas práticas individuais e coletivas, os fenômenos de "incorporação" como modo de manifestação dos problemas, e a ação do corpo nos fenômenos de ritualização e fanatização. É como se a linguagem fosse aqui principalmente corporal, cabendo à linguagem propriamente dita só uma função de apoio.

Quanto à função das palavras consideradas propriamente como elementos simbólicos, sua função apresenta semelhanças quanto ao fato de que tanto na Umbanda quanto nas Renovadas se trata de veicular significados. Porém quanto ao modo como são utilizados esses significados, ressaltam-se as diferenças entre uma prática de cura e a outra. Nas Renovadas o acentuado caráter imaginário de seus procedimentos decorre, entre outros fatores, de que se dê mais ênfase e importância ao modo como são proferidas as palavras e à autoridade de quem as emite, do que ao significado, que também não deixam de veicular. $O$ acento fica 
nas manifestações de tipo catártico e na valorização da experiência emocional no contato com Cristo. Uma espécie de ênfase no efeito mágico das palavras está sempre presente nas orações, exortações e prescrições.

$\mathrm{Na}$ Umbanda a palavra adquire um teor sofisticado e uma densidade simbólica que chegam a rivalizar com a função imaginária que também é bastante acentuada. Os caracteres imaginários, se assim podemos chamar aos diferentes contornos adquiridos pelos guias:" pretos-velhos","caboclos", "pombagiras", são vivenciados sobre o fundo das configurações simbólicas dos mitos afro-indígenas. Esses mitos possuem a função estrutural de deciframento, conectando o sujeito psicologicamente com seu sofrimento: possuem função de simbolização, fornecendo uma espécie de personificação e tradução, em termos sócioculturais, das dores, angústias e impasses de caráter individual; desempenham ainda uma função de elaboração dos conflitos, no sentido que esta possui na psicanálise. Pode-se dizer que aí se traduz e elabora o mito individual nos termos do mito coletivo.

Do ponto de vista da psicanálise o que ocorre nestes casos é uma operação psíquica que consiste na estabilização e localização de um gozo desordenado e transbordante corporalmente, em um gozo localizado no Outro: orixá, no espaço e tempo do ritual (Quinet, 1997). Nesse processo o gozo próprio é atribuído à entidade que se incorpora, passando o próprio sujeito a gozar claramente sob a forma da beatitude ${ }^{9}$. A ilustração clara desta circunstância é facilmente visível nos rituais de "incorporação"com destaque para as "pombagiras"10, personificações da própria "beatitude",em forma de gozo feminino, e para os exus, personificações de um gozo mais encarniçado em que o corpo parece sofrer a ação de uma gravidade multiplicada e contorções contrárias à sua disposição natural (dados de observação).

Entremeando os diferentes atos dos corpos entregues ao ritual, estes em si mesmo imprescindíveis, está o diálogo das palavras carregadas da consistência simbólica dos mitos coletivos. Essa conjunção de atos e palavras propicia a estruturação de vínculos entre curandeiros e clientes, tanto na situação bi-pessoal quanto em situações grupais como as Giras ${ }^{11}$, que possuem grande semelhança com algumas formas de vínculo transferencial concebidas na psicanálise ("capacidade reverie" e "função

9 Gozo místico relacionado com a contemplação divina. Lacan (1982), o relaciona ao gozo feminino (não apenas das mulheres), cuja expressão e percepção se dá no corpo como todo. As "pombagiras" parecem gozar do oferecimento do próprio corpo a um suposto olhar para o qual dançam ao se apresentarem na Gira.

10 Exu feminino, aparece na Umbanda popular e Quimbanda com vários nomes, mas sempre faceira e provocante, ao baixar no Terreiro. Usa sempre vestidos ou saias longas, plumas, bijuterias, etc.. Quanto ao Exu propriamente dito, trata-se da personificação do demônio em figuras diversas. (Cacciatore, 1977).

11 Gira: cerimônia rotineira semanal de culto às entidades umbandistas, geralmente em dias e horários fixos, que compreende também os momentos de incorporação dessas entidades e o atendimento ao público presente que quer consultar-se com elas (Cacciatore, 1977). 
alfa" do psicanalista, Bion (1988) e "dimensão imaginária da transferência" Miller (1988)).

Quanto á maior ou menor complexidade dos procedimentos em sua relação com a maior ou menor gravidade dos problemas, convém distinguir algumas nuances importantes quanto aos possíveis fundamentos da eficácia das práticas de cura místico-religiosas. Se considerarmos essas problemáticas em termos de demanda de significação, podemos pensar também que pode haver diferenças de grau entre essas "faltas de significação". Chamemos de falta radical de significação aqueles casos em que a própria integridade da experiência psíquica parece ameaçada (aqui se incluem os indivíduos "chamados" a desenvolver no santo e aqueles em que se opera a adesão fanática). Chamemos, por outro lado, faltas secundárias de significação àquelas ocorrências em que o sujeito chega a entrar em contato com estados de terror (estranhamento), de angústia ou ansiedade com diferentes graus de tolerância, mas sem risco aparente de desestabilização radical da organização psíquica.

As ocorrências do primeiro tipo são aquelas que temos denominado demandas radicais de sentido de teor imaginário em maior ou menor grau (em neuroses histéricas graves). Os procedimentos de cura que lhes correspondem são os que geralmente acarretam a ritualização e a fanatização da relação dos indivíduos com as instituições de cura. As mudanças nesses casos parecem ocorrer pelas transformações psíquicas produzidas por cada um dos processos de desenvolvimento subjetivo, transformando a vida dos indivíduos, através da adição de sentido, mas junto com ela, da adição de um vínculo institucional capaz de dar à identidade, outro sentido e status.

Na segunda categoria de problemas, incluindo mesmo algumas doenças somáticas crônicas, nas quais a atitude do sujeito é um importante fator, os efeitos conseguidos parecem decorrer, além da adição de sentido, da mudança de atitude, seja nos episódios de vida mais amplos, seja em termos de experiências associadas a eventos específicos de caráter traumatizante. Estas mudanças de atitude também não deixam de ter efeitos em muitos casos, que nem sempre se poderia qualificar de secundários quanto ao valor. Reorganizando a atitude dos indivíduos em relação aos próprios problemas, via de regra, pela reposição de uma fé na solução, permite-se que eles se reposicionem subjetivamente em relação a si próprios, à sua história presente e à vida cotidiana. De sofredor passivo, descrente e às vezes desorientado, ele comumente passa a agente a serviço da sua cura e transformação. Os efeitos subjetivos e sócioculturais decorrentes da inclusão que se produz quando o sujeito se vincula a uma instituição, e com isso na um grupo de pares com problemas e objetivos semelhantes, também somam na mesma direção. Parece haver aqui em todos os casos uma espécie de re-filiação. 
A eficácia das práticas místico-religiosas também depende da sua maior sintonia com as visões de mundo dos seus adeptos, o que lhes permite oferecer soluções, de imediato, mais assimiláveis. Nos dois casos das práticas místico-religiosas pesquisadas, a adição de sentido, instrumentada através da fé como um meio de engajamento dos indivíduos na solução dos seus problemas, parece propiciar uma atitude ativa que tende a derivar-se para a vida como um todo. Os curandeiros atuam a partir de um lugar muito preciso na subjetividade dos adeptos, o que confere às suas palavras e seus atos um caráter de transcendência; fala-se do lugar do"santo" ou de Jesus.

A eficácia das práticas de cura místico-religiosas não parte de uma ação indiscriminada. Nelas a demarcação de fronteiras entre o que é definido como perturbação espiritual e o que é patologia, derivável ao saber das ciências, existe e é variável nos dois tipos de instituição. Nas Pentecostais a certeza é do tipo paranóico, não há divisão do sujeito."Jesus tudo pode" contra Satanás; num gnosticismo exacerbado é o mundo que fica dividido. Não há um saber e sim um poder para curar, poder que vem diretamente de Jesus. Essa postura de arrogância e onipotência determina uma atitude de negação das outras formas de fé e de ajuda; só a ajuda médica é reconhecida, e apenas em casos extremos. Na Umbanda a certeza também tem matiz paranóico, mas expressa-se como saber, ou como poder que deriva em saber ancestral. O "guia sabe" diante da modéstia do sujeito que o incorpora (pai ou mãe-de-santo); atitude oposta à dos Pentecostais. Sem arrogância ou onipotência, há um reconhecimento aberto dos outros saberes.

Finalmente, vale a pena indicar que essa eficácia parece ter relação com o momento histórico.Ou seja, a forma de incidência das práticas de cura místico-religiosas na subjetividade de seus adeptos, particularmente dos fanatizados, em paralelo com a alta freqüência, entre estes, de sintomas relacionados com as drogadições (alcoolismo e toxicomanias) e com a depreciação da auto-imagem (alta freqüência de mulheres sem inserção econômica e sóciocultural, e de desempregados crônicos), nos levou à hipótese de que estas práticas funcionam como "ortopedias" das "deficiências" do individualismo contemporâneo típico da ética liberal pós-moderna (capitalismo globalizado). Elas parecem acabar repondo, ou tentando repor, com meios sintônicos aos sintomas, uma certa funcionalidade da "categoria indivíduo",através de um conjunto de práticas de ascese fundadas em ideais solipsistas.(pregando o sucesso individual a despeito de quaisquer adversidades). É possível considerar que os indivíduos que a elas recorrem encontram-se afetados de sofrimentos que vêm permeados pelas "doenças" que acometem o "individualismo": baixa auto-estima, impossibilidade de autodeterminação (seja pelos vícios, seja pela incapacidade de se fazer valer no mercado de trabalho ou na esfera do consumo), eclipse dos ideais, e casos mais graves que chegam á desfiliação (ausência 
total de laços econômicos, sociais e subjetivos, Castel, 1995), entre outras. Os meios de tratamento oferecidos, sobretudo, pelas Pentecostais Renovadas têm no cerne a própria ideologia da ascese, associada à promessa do sucesso individual, eis mais um forte ingrediente do sucesso de suas "curas".

\section{0 estatuto ético dos efeitos das práticas de cura místico-religiosas}

Vale a pena esclarecer que a questão sobre o estatuto ético deve ser posta não apenas às práticas de cura místico-religiosas, mas às práticas de quaisquer instituições que atuem no campo dos tratamentos psíquicos, independentemente de seus matizes teórico-técnicos e ideológicos. religiosas?

Qual é o Estatuto ético dos efeitos das práticas de cura místico-

Serão associáveis a efeitos adaptativos de alienação, do tipo serialização (massa-líder) ou permitirão alguma brecha na direção da singularização, propiciando abertura para os ideais, o desejo e o carecimento $^{12}$ ?

Os efeitos típicos em termos terapêuticos e éticos das práticas de cura místico-religiosas parecem estar na esfera da adaptação, isso não impediu, entretanto, de serem considerados um ganho importante para a maioria dos sujeitos que os obtiveram. A possibilidade de interferência no funcionamento subjetivo, também pareceu bastante significativa: pela fé, os sujeitos acabaram se engajando numa relação mais ativa com os problemas que os tinham feito recorrer; porém quando se trata de pensar as modalidades deste engajamento subjetivo, nota-se que seus efeitos de singularização são bastante limitados, persistindo os de serialização como a modalidade mais comum. Note-se de passagem, que neste ponto a ação dos Ambulatórios não destoou. Os efeitos obtidos no re-posicionamento subjetivo dos indivíduos parecem ter-se dado à custa da hipoteca de uma parte importante da subjetividade (mesmo com variações importantes entre as instituições estudadas), ou seja, a estabilização subjetiva obtida apoia-se na alienação de parte importante da própria capacidade dos indivíduos, de resolução dos próprios problemas, que fica depositada no Outro-divindade ou na medicação. Devese ressaltar a exclusão da dimensão coletiva, da qual os indivíduos tam-

Carecimento, por oposição ao conceito de carência ou de necessidade, abarca uma dimensão do homem que inclui o desejo (como se o propõe na psicanálise) e toda a abertura para os Ideais, possíveis ou não de imediato, e para o usufruto de todos os bens da produção social, muito além do preenchimento de necessidades, no contexto de determinada Formação Social. Pode-se considerar que aqui estão incluídas também as criações da Filosofia, da Arte, da Ciência, e da Religião, porém não sem passar pela aspiração pertinente ao usufruto das comodidades socialmente produzidas no mais alto grau da sua evolução histórica (Marx, Manuscritos de 1844) 
bém permanecem alienados, remetendo-se as soluções dos impasses e doenças sempre à individualidade. A remoção dos problemas talvez possa ser alinhada em uma ética de duplo eixo articulando eu-realidade e carência-suprimento, como meios capazes de produzirem adaptação, coerentes com sua natureza de instituições místico-religiosas. Claro está que não se trata de exigir destas práticas que contrariem sua vocação, limitamo-nos a constatar para esclarecer; entretanto efeitos de outra natureza devem ser exigidos das práticas fundadas no saber oficial, como as dos Ambulatórios: a substituição dos eixos eu-realidade e carênciasuprimento por outros capazes de girarem em torno dos conceitos de sujeito-desejo e carecimento-Ideais, que podem ser propostos como uma bússola capaz de desalojar os procedimentos de alienação e tutela e substitui-los por outros em que a implicação subjetiva por singularização que Ihes corresponde, possa ser fim e horizonte.

Qual o destino da transferência de saber operada por estes clientes junto às instituições a que recorreram?

Freud (1918) a propósito da aplicação popular da psicanálise às grandes massas, diz que ter-se- á, talvez, que mesclar o ouro puro da psicanálise ao cobre da sugestão direta. Porém sublinha que

qualquer que seja a composição desta terapia para o povo, seus elementos mais importantes e eficazes deverão ser tomados da psicanálise propriamente dita, rigorosa e livre de toda a tendência... recusamo-nos decididamente a adonarmo-nos do paciente que se põe em nossas mãos, de estruturar o seu destino, impondo-lhe nossos ideais e formá-lo, com orgulho criador, à nossa imagem e semelhança. (p. 2460, tradução nossa)

Num significativo número de casos percebe-se que o tratamento reproduz a estrutura do sintoma, mesmo que com efeitos visíveis de apaziguamento da angústia.Essa característica fica claramente ilustrada com a adesão fanática, que alguns sujeitos expressam em forma de um lema pessoal; “meu único vício agora é Jesus". Daí poder-se-ia concluir que as soluções reproduzem o modo estrutural dos sintomas, o que deixa claro o estatuto ético dos seus efeitos: são adaptativas às condições dadas da realidade sócio-cultural e ego-sintônicas, contribuindo para a manutenção do status de alienação social e subjetiva presentes no contexto e no momento em que se gerou a procura de ajuda.

Portanto, quando pensadas à luz da sua possibilidade de produção de subjetividade singularizada, não passaram no teste. A uma distância larga da singularização, produzem identificações em que o estatuto do "objeto" permanece na esfera do narcisismo (eu ideal); o que parece predominar é a identificação a um "eu suposto possuidor da verdade revelada" e não a identificação a ideais de estatuto sóciocultural. 
Entretanto, convém afastar a idéia de que se esteja propondo substituição das práticas de cura místico-religiosas por outras de alcance teórico-técnico e ético mais compatível com o ldeal da singularização. Infelizmente não é possível pôr as questões de modo tão esquemático. Procuramos mostrar ao longo de todo este trabalho como a formulação de dispositivos institucionais como as práticas de cura nas religiões, no contexto sóciocultural, é resultante da conjunção de uma série complexa de fatores: como o estado das subjetividades e as características sócio-econômico-culturais dos indivíduos; as características mais amplas da formação social (Cultura do Narcisismo e Cultura do Misticismo); transformações do campo religioso como possíveis efeitos do neoliberalismo globalizado (sujeitos à margem da circulação econômica e simbólica); a lógica do mercado capitalista, como fator importante, regendo a relação entre a oferta e procura de "serviços de cura"; e a precariedade das ofertas do saber oficial.

\section{III - Desdobramentos da análise: Cultura do Misticismo}

Uma conclusão central deste trabalho indica que a procura crescente das práticas de cura místico-religiosas pode estar relacionada com a exacerbação dos efeitos da Cultura do Narcisismo, em uma de suas variantes, principalmente para indivíduos que estão à margem da circulação social (da produção e do consumo, tanto de bens materiais quanto simbólicos). Em outras palavras, uma parte do conjunto dos efeitos da Formação Social neoliberal globalizada na subjetividade parecem manifestar-se em nossos sujeitos, exacerbando uma tendência cultural, já presente, para explicações de caráter místico-religioso frente às vivências de estranhamento, desamparo e mesmo nos estados de sofrimento derivados dos diferentes desarranjos psíquicos. Parece haver uma relação de mútuo incremento entre as ofertas sentido "místico-religioso" de teor imaginário, e essa espécie de inércia das subjetividades manifesta em demandas de sentido de mesma natureza e consistência (complementaridade objetal do tipo "eu ideal"). Parte importante dessa demanda de complementaridade tende a ser dirigida às práticas místico-religiosas que, como vimos possuem um leque amplo de matizes de resposta, desde o sentido imaginário mais assentado em referenciais simbólicos como o da Umbanda até o sentido de teor imaginário radical como o da práticas de concretização das Pentecostais.

Assim, como explicação do"misticismo generalizado" nos grandes centros urbanos brasileiros (mas não apenas neles), elaboramos a hipótese sobre a existência de uma "Cultura do Misticismo" em processo avançado de implemento, como um caso particular da tendência geral ao enfraquecimento das relações do homem com o campo do Simbólico, no contexto dos efeitos gerais das sociedades de consumo avançadas, com destaque para a ex- 
clusão social acentuada na fase globalizada dessas sociedades e para a crise de sentido conseqüente ao abalo dos Ideais mais basilares do liberalismo. $\mathrm{A}$ tendência ao misticismo ganharia visibilidade, então, como um caso particular da Cultura do Narcisismo proposta por Lasch.

A Cultura do Misticismo também pode ser definida pela presença acentuada e crescente das demandas por adição de sentido de teor imaginário, e por uma certa suscetibilidade a modos de gozo que fazem um curto-circuito do simbólico, ou seja, que mantêm a exigência de imediatismo e totalização, como as adesões fanáticas e os consumismos compulsivos. Como desdobramento dessa hipótese, nossa análise indicou que a atitude mística, quando assumida como resposta ao mal-estar cotidiano, pode ter uma estrutura congruente com as formas dos sintomas mais comuns nestas sociedades: compulsões, pânicos, depressões, desfiliações; e chega a funcionar para muitos indivíduos como barreira contra a possibilidade de deriva para essas formas de angústia, diante das quais só restaria a habitação do sintoma ou o recurso medicamentoso (conforme a representação do adoecer que é mais comum e dos meios de tratamento à disposição no contexto em que vivem estes indivíduos); mesmo que, como vimos anteriormente, essas formas de adição de sentido possam ter custos subjetivos bastante altos.

A hipótese da existência de uma Cultura do Misticismo pareceunos também o argumento maior capaz de explicar o crescimento acelerado das Igrejas Pentecostais Renovadas e do grupo dos Carismáticos da Igreja Católica Romana, das religiões afro-brasileiras e do misticismo em geral. A Cultura do Misticismo seria causa e efeito do aumento vertiginoso das demandas radicais de sentido de teor imaginário, associadas à presença, no contexto social, de ofertas de sentido da mesma consistência, organizadas segundo os princípios e a lógica capitalista do mercado. A forma sob a qual se configuram essas demandas e sua manifestação, provavelmente é associável às situações de indigência econômica, desenraizamento sóciocultural e subjetivo, com seus diferentes matizes; e ao declarado fracasso dos Ideais da Formação Social em que o fenômeno ocorre, para esses grupos de indivíduos excluídos ou em processo de exclusão social (processo agravado em contextos de capitalismo dependente como o brasileiro). A hipótese de uma Cultura do Misticismo está em consonância com a hipótese de Lacan (2005), sobre o triunfo da religião nos tempos de globalização, cujo alcance devemos ampliar: triunfo das religiões e dos misticismos, num contexto em que já era acentuada sua presença. $\mathrm{O}$ monopólio de depositários do sentido radical de teor imaginário, dos misticismos e das religiões só recentemente tem sido arranhado pela medicalização dos impasses psíquicos operada pela Ciência; quanto à psicanálise, esta só muito recentemente vem formulando, no contexto da Saúde Coletiva, as ofertas de possibilidades de transferência que decorrem de sua ética. 


\section{Mystic-Religious Cure Practices, Psychotherapy, And Contemporary Subjectivity}

Abstract: We have analyzed the results of an inquiry about mystic-religious cure practices (within both Protestant and Renovated Catholic Churches, as well as Umbanda afro-american spiritualism). Along with the comparison between those results and treatment, in Mental Health public nurseries, of individuals complaining from mental discomfort..The statistic analysis revealed mystic-religious cure practices are efficacious at the solution of problems from those who recurred to these practices, overcoming, in the short term, the efficacy obtained by the nurserial practices. One of the main means for the mystic-religious cure practices efficacity consists in the meaning-providing from various hues, featuring the radical, imaginaryessence meaning, generating, in many cases, the institutional or ritualistic, fanactic kind conversion. Mystic-religious cure practices seem to function like contemporary individualism "illnesses"' orthopedia, restoring, with sintony to the symptoms, some individual category's functionality. As the survey unfolds, we came to the hypothesis about the existence of a "Mysticism Culture", in advanced stage of formation within the Brazilian context, as a consequence of cultural features, as well as of the effects from subjective relation disturbances towards the symbolic field, inside globalized consummation societies with sharp social excludance rates and affected by an important meaning crisis following the weakening of the most basic ideals of liberalism.

Keywords:Mystic-religious cure.Subjectivity.Psychotherapy. Collective mental health. Mysticism.

\section{Pratiques Mystico-Religieuses De Guérison, Psychothérapie Et Subjectivité Contemporaine}

Resumé: Nous avons analysé les résultats d'une recherché sur les pratiques de guérison mystico-religieuses (chez les Églises Évangéliques et Catholique Renovée, et chez l'Oumbanda). Ainsi que leur comparaison avec le traitement fourni, chez les Ambulatoires de Santé Mentale publiques, aux individus se plaignant de souffrance psychique. L'analyse statistique a révélé que les pratiques de guérison mystico-religieuses sont efficaces à la solution des problèmes de ceux qui les ont cherché, en surmontant, dans le court délai, l'efficacité obtenue par les pratiques ambulatoriales. Un des principaux moyens d'efficacité des pratiques de guérison mystico-religieuses consiste dans l'offre de sens de diverses nuances, d'où se ressort le sens radical de teneur imaginaire, qui implique en des adhésions institutionelles du type fanatique ou ritualistique en bonne partie des cas. Les pratiques de guérison mystico-religieuses semblent fonctioner comme des orthopédies 
des "maladies" de l'individualisme contemporain, en réinstallant, par des moyens syntoniques, quelque fonctionalité de la catégorie individu.Comme suite de l'analyse, nous arrivons à l'hypothèse sur l'existence d'une "Culture du Mysticisme" en état avancé de formation dans le contexte brésilien, comme conséquence des caractéristiques culturelles et des effets de la perturbation des rapports du sujet avec le domaine du symbolique, dans les sociétés de consommation mondialisées à exclusion sociale accentuée et affectées par une importante crise de sens, conséquence de l'ébranlement des idéaux les plus basilaires du libéralisme.

Mots-clés: Pratique mystico-religieuses de guérison. Subjectivité. Psychothérapie. Santé mentale collective, Mysticisme.

\section{Prácticas curativas místico-religiosas, psicoterapia y subjetividad contemporânea}

Resumen: Analizamos los resultados de una investigación acerca de las prácticas curativas místico-religiosas (católicas y evangélicas renovadas, y Umbanda). Y su comparación con el tratamiento los Ambulatorios de la Salud Mental públicos, para las personas con las quejas de sufrimiento psíquico. El análisis estadístico mostró que las prácticas de curación místico -religiosas son eficaces en la solución de los problemas que las procuram, superando, en corto plazo, la eficacia obtenida por las prácticas de los Ambulatorios. Uno de los principales medios de eficácia de las prácticas de curación místico -religiosas es la adición de sentido de diversos matices, com destaque para el sentido radical de contenido imaginario, que requiere la pertenencia a instituciones de tipo ritual o fanático, em gran parte de los casos. Las prácticas curativas místico-religiosas parecen actuar como ortopedias de "enfermedades" del individualismo contemporáneo, sustituiendo con medios sintônicos a los síntomas alguna funcionalidad de la categoria individuo. Cómo desdoblamiento del análisis hemos llegado a la hipótesis sobre la existencia de una "cultura del misticismo" en una fase avanzada de su formación en el contexto brasileño, como consecuencia de las características culturales y de los efectos de la perturbación de las relaciones de los indivíduos con el campo del Simbólico, en las sociedades de consumo globalizado. Sociedades com una importante exclusión social y afectadas por una fuerte crisis del sentido consecuente a lo golpe a los ideales más básicos del liberalismo.

Palabras clave: Prácticas curativas místico-religiosas, subjetividad contemporánea, psicoterapias, Salud Mental Colectiva, "Cultura del Místissismo" 


\section{Referências}

Antoniazzi, A. (Org.). (1994). Nem anjos nem demônios: interpretações sociológicas do Pentecostalismo. Rio de Janeiro: Vozes.

Bion, W. R. (1988). Estudos psicanalíticos revisados (W. M. M. Dantas, trad.). Rio de Janeiro: Imago.

Brandão, C. R. (1994). A crise das instituições tradicionais produtoras de sentido. In A. Moreira \& R.Zicman, Misticismo e novas religiões (2a ed.). Rio de Janeiro: Vozes.

Cacciatore, O. G. (1977). Dicionário de cultos afro-brasileiros (2a ed.). Rio de Janeiro: Forense Universitária.

Costa-Rosa, A. (1999). Curas místico-religiosas e psicoterapia. Revista Estudos de Religião, 16, 123-139.

Costa-Rosa, A. (1995). Práticas de cura nas religiões e tratamento psíquico em saúde coletiva. Tese de Doutorado, Universidade de São Paulo, São Paulo.

Freud, S. (1914). Introduccion al narcisismo. In S. Freud, Obras completas (Tomo II, L.Lopez Balesteros y de Torres, trad.). Madrid:Bibioteca Nueva.

Freud, S. (1915). La represion. In S. Freud, Obras Completas (Tomo II, L. Lopez Balesteros y de Torres, trad.). Madrid: Bibioteca Nueva.

Freud, S. (1918). Los caminos de la terapia psicoanalitica. In S. Freud, Obras completas (Tomo III, L. Lopez Balesteros y de Torres, trad.). Madrid: Biblioteca Nueva.

Freud, S. (1921). Psicologia de las massas e analisis del Yo. In S. Freud, Obras completas (Tomo III, L. Lopez Balesteros y de Torres, trad.). Madrid: Biblioteca Nueva.

Freud, S. (1927). El porvenir de una ilusion. In S. Freud, Obras completas (Tomo III, L. Lopez Balesteros y de Torres, trad.). Madrid: Biblioteca Nueva.

Freud, S. (1929/30). El malestar en la cultura. In S. Freud, Obras completas (Tomo III, L. Lopez Balesteros y de Torres, trad.). Madrid: Biblioteca Nueva.

Freud, S. (1932). Nuevas lecciones introductorias al psicoanalisis (lição XXXV - El problema de la concepciçn del Universo). In S. Freud, Obras completas (Tomo III, L. Lopez Balesteros y de Torres, trad.). Madrid: Biblioteca Nueva.

Castel, R. (1995). Lês piéges de l'exclusion. In Lien social et politique. RIAC. 34. Montreal: Ecole de Service Social, Université de Montreal. 
Haley, J. (1993). As táticas e o jogo de poder de Jesus Cristo (J. Gargioni, \& Z. Werner, trads.). Rio de Janeiro: Nódica.

Kopnin, P. V. (1978). A dialética como lógica e teoria do conhecimento (P. Bezerra, trad.). Rio de Janeiro: Civilização Brasileira.

La Platine, F. (1977). Mesianismo, posesion y utopia: las tres voces de la imaginacion colectiva (H. Azevedo, trad.). Barcelona: Granica.

Lacan, J. (1979). O seminário. Livro 11: Os quatro conceitos fundamentais da psicanálise (M. D. Magno, trad.). Rio de Janeiro: Zahar.

Lacan, J. (1982). O seminário. Livro 20: Mais, ainda (M. D. Magno, trad.). Rio de Janeiro: Zahar.

Lacan, J. (2005). O triunfo da religião (A.Teles, trad.). Rio de Janeiro: Zahar.

Lasch, C. (1983). A cultura do narcisismo (H. P. Moura, trad.). Rio de Janeiro: Imago.

Lévi-Strauss, C. (1975). Antropologia estrutural (C. S. Katz \& E. Pires, trads.). Rio de Janeiro:Tempo Brasileiro.

Lewis, I. M. (1971). Êxtase religioso (J.R.S.Madureira, trad.). São Paulo: Perspectiva.

Lindholm, C. (1993). Carisma (C. A. C. Ribeiro, trad.). Rio de Janeiro: Jorge Zahar.

Loureau, R. (1975). Análise institucional (M. Ferreira, trad.). São Paulo: Vozes.

Magnani, J. G. (1989). O neo-exoterismo na cidade. Revista USP, (31), 5-15.

Maleval. J. C. (1987). Loucuras histéricas y psicoses dissociativas (J. Piatigorsky). Barcelona: Paidós.

Mariz, S. L. (1994). Libertação e ética. Uma análise do discurso de pentecostais que se recuperaram do alcoolismo. In A. Antoniazzi (Org.), Nem anjos nem demônios: interpretações sociológicas do pentecostalismo. Rio de Janeiro: Vozes.

Marx,K.(1978).Manuscritos econômico-filosóficos de 1844 (J.C.Bruni, trad.). São Paulo: Abril Cultural.

Merleau-Ponty, M. (1971). Fenomenologia da percepção (R.Di Piero, trad.). Rio de Janeiro: Freitas Bastos.

Miller, J. A. (1988). Percurso de Lacan: uma introdução (A. Roitman, trad.). Rio de Janeiro: Jorge Zahar.

Minayo, M. C. (2000). O desafio do conhecimento: pesquisa qualitativa em saúde. Rio de Janeiro: Hucitec. 
Montero, P. (1985). Da doença à desordem. Rio de Janeiro: Graal.

Moreira, A., \& Zicmen, R. (1994). Misticismo e as novas religiões. Rio de Janeiro:Vozes.

Paiva, G.J.(1990).Instituição religiosa perfeita liberdade.In L.Landin (Org.), Sinais dos Tempos - igrejas e seitas no Brasil (pp. 187-183). Rio de Janeiro: Instituto de estudos da Religião.

Paiva, G. J. (1990). Algumas relações entre psicologia e religião. Psicologia USP, 1(1),25-33.

Platão. (1967). Diálogos (J. Bruna, trad.). São Paulo: Cultrix.

Quinet, A. (1991). As 4+1 condições da análise. Rio de Janeiro: Jorge Zahar.

Quinet, A. (2003). Teoria e clínica da psicose. Rio de Janeiro: Forense Universitária.

Sarti, I., \& Valle, R. (1994). O risco das comparações. In A. Antoniazzi (Org.), Nem anjos nem demônios: interpretações sociológicas do pentecostalismo. Rio de Janeiro: Vozes.

Silva, M. L. (1993). Investigação e psicanálise. Campinas, SP: Papirus.

Simon, R. (1983). Psicologia clínica preventiva: novos fundamentos. São Paulo: EPU.

Sloterdijk, P. (1989). Crítica de la razon cínica I (M. A. Vega, trad.). Madrid: Taurus Humanidade.

Terrin, A. N. (1996). Nova era - a religiosidade do pós-moderno. São Paulo: Loyola.

Trindade, L. (1979). Exu: símbolo e função. Tese de Doutorado, Universidade de São Paulo, São Paulo.

Abílio da Costa-Rosa, Professor da Universidade Estadual Paulista, Faculdade de Ciências e Letras, Curso de Psicologia, Caixa Postal 819 CEP 19814- 970, Assis - SP. Endereço Eletrônico:abiliocr@assis.unesp.brAssis

Recebido em: 23/02/2007

Aceito em: 18/11/2007

4 Abílio da Costa-Rosa 